\title{
ANALISIS SISTEM PENJUALAN ONLINE PADA PERUSAHAAN GARMENT DI SEMARANG
}

\author{
Tri Listyorini ${ }^{1}$ \\ Program Studi S1Teknik Informatika,Fakultas Teknik, Universitas Muria Kudus \\ Gondangmanis, Bae PO. BOX : 53, Telp: 0291-438229, Fax: 0291-437198 \\ E-mail: muria@umk.ac.id http://www.umk.ac.id
}

\begin{abstract}
ABSTACT
The number of requests made in fashion Central Java city of Semarang became one of the central production of the garment with a variety of models and fashion brands available. With the marketing considerations that are not only in the local area alone, many garment companies in the city of Semarang applying online sales as a way to expand the marketing network of garment products.

This study menghasilan a web-based sales information system designed as a promotional medium garment products, expand the sales area, and to shorten and simplify the transaction. Data collection methods used include interviews, ie questions and answers directly to the sources of required data. Another method is to literature, that is by collecting references related to the topic of the author, namely PHP, Website and Sales System.
\end{abstract}

Key words: Information Systems sales, website

\begin{abstract}
ABSTRAKSI
Banyaknya permintaan di bidang fashion menjadikan kota Semarang Jawa Tengah menjadi salah satu sentral produksi garment dengan berbagai model dan merk fashion yang ada. Dengan pertimbangan pemasaran yang tidak hanya di daerah setempat saja, banyak perusahaan garment di kota Semarang menerapkan penjualan online sebagai salah satu cara untuk memperluas jaringan pemasaran dari produk garment.

Penelitian ini menghasilan sebuah sistem informasi penjualan berbasis web yang dirancang sebagai media promosi produk-produk garment, memperluas area penjualan, serta mempersingkat dan mempermudah transaksi.

Metode pengumpulan data yang digunakan meliputi metode wawancara, yaitu tanya jawab secara langsung terhadap sumber-sumber data yang dibutuhkan. Metode yang lain adalah kepustakaan, yaitu dengan mengumpulkan referensi-referensi yang berhubungan dengan topik penulis, yaitu PHP, website dan Sistem Penjualan.
\end{abstract}

Kata kunci : Sistem Informasi penjualan, website

${ }^{1}$ Dosen Program Studi S1 Teknik Informatika UMK Kudus, Email : trilistyorini.ti.umk@gmail.com 


\section{PENDAHULUAN}

\section{a. Latar Belakang}

Dengan adanya kemajuan dalam bidang Teknologi Informasi saat ini, baik dari segi perangkat keras, perangkat lunak dan teknlogi komunikasi yang begitu cepat berkembang, perusahaan atau instansi mulai merasakan bahwa teknologi informasi ini diterapkan untuk memenuhi kebutuhan informasi sehingga dapat mendukung proses pengambilan keputusan yang dilakukan oleh manajemen.

Perusahaan garment merupakan contoh perusahaan berskala besar yang telah berpengalaman dalam mengelola segmen bisnis garment. Perusahaan garment beroperasi secara komersial di daerah Salatiga Jawa Tengah. Produk utama yang dihasilkan adalah berbagai jenis produk garment.

Penulis mencoba menawarkan untuk membuat sebuah web untuk menjangkau buyer atau masyarakat di dalam maupun di luar negeri. Web tentang penjualan berbagai jenis produk garment yang diproduksi oleh Perusahaan garment ini akan disertai dengan katalog penjualannya. Dengan adanya penjualan secara on-line tersebut, penulis merasa akan lebih efektif untuk melakukan penawaran dan transaksi produk yang ada pada Perusahaan garment, karena bukan hanya buyer itu saja yang mengetahui keberadaan Perusahaan garment tetapi buyer lain dan masyarakat umum juga dapat mengenal perusahaan garment tersebut.

Sistem penjualan yang baik saat ini adalah sitem yang berbasiskan pada jaringan. Maksudnya, system penjualan ini bersifat online. Adapun manfaat dari pada system ini bisa dirasakan bagi kedua belah pihak yakni pihak penjual dan pembeli.

Bagi para penjual, menerapkan system seperti ini berarti memangkas pengeluaran yang biasa dikeluarkan dalam system lama. Seperti, jika pada system lama kita harus membuka cabang baru demi melebarkan sayap bisnis kita, tidak dengan system online. Karena dengan system ini penjual dapat memperkenalkan hasil produknya ke halayak melalui suatu web. Dimana setiap orang (konsumen) tidak hanya di satu lokasi bisa mengakses untuk mencari informasi akan barang yang diperlukan, tanpa perlu membuka cabang/kantor pemasaran baru.

Bagi para konsumen, system ini sangatlah membantu. Karena konsumen tidak perlu datang langsung ke lokasi untuk membeli barang yang diinginkan, mengingat kondisi lalu-lintas kota yang cukup ramai yang menyebabkan terlalu banyak waktu yang kita buang dijalan untuk sampai ke lokasi. Maka dengan system penjualan online ini, konsumen bisa mendapatkan barang yang diinginkan cukup dari tempat duduknya.

Manfaat sistem penjualan online :

1. Tidak perlu membuka banyak kantor cabang dalam hal pemasaran.

2. Mengurangi tingkat pengeluaran bagi pihak produsen

3. Memudahkan para konsumen dalam pembelian suatu barang. 


\section{b. Tujuan}

Berdasarkan uraian pada latar belakang di atas, maka pembahasan dalam paper ini bertujuan perusahaan dapat memanfaatkan website ini sebagai media untuk memperkenalkan atau mempromosikan produk maupun bisnis yang dikembangkan oleh perusahaan tersebut melalui media internet atau setidaknya dijadikan referensi untuk membuat website yang baik.

Dekomposisi HIPO

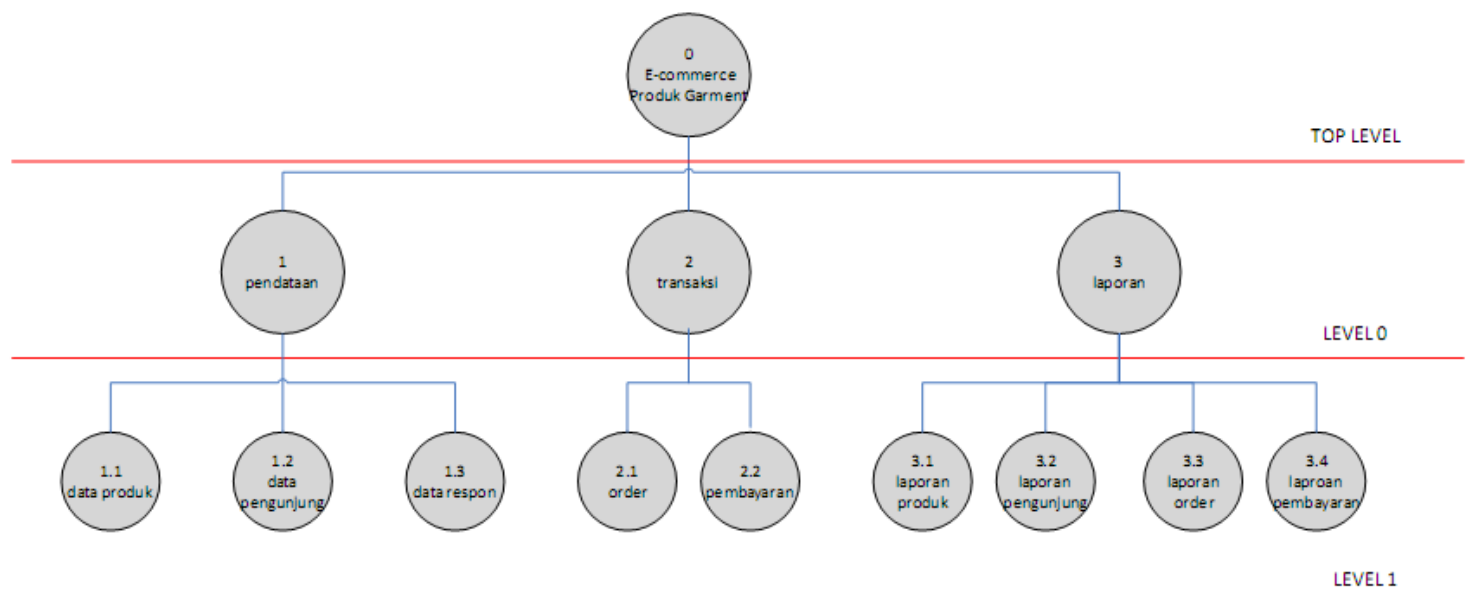

METODE PENELITIAN

a. Metode penelitian dalam Sistem Penjualan Produk Garment

Metode yang akan digunakan dalam penelitian ini terdiri dari langkahlangkah sebagai berikut :

a. Penelitian dilakukan di Perusahaan garment Semarang.

b. Metode pengumpulan data dengan wawancara.

c. Merancang data apa saja yang dibutuhkan dalam pembuatan website penjualan perusahaan.

d. Melakukan pengujian terhadap aplikasi website yang telah dibuat dengan mengenalkan aplikasi website ini terhadap masyarakat.

Dalam Penelitian ini pendekatan yang diajukan adalah metode berorientasi objek dengan tahapan-tahapan, requirment (kebutuhan), analysis (analisis), design (perancangan), implementation (Pemakaian), dan testing (pengujian), tahapantahapan dilakukan secara overlap dan bersiklus.

a. Requirment (kebutuhan)

Pada tahap requirement, penulis mengumpulkan informasi-informasi serta permasalahan yang terkait dengan penelitian ini kemudian merumuskannya menjadi suatu batasan permasalahan yang menjadi topik penelitian ini. 


\section{b. Analysis (Analisa)}

Pada tahap analisis, penulis melakukan peninjauan ulang secara lebih mendalam terhadap objek yang menjadi penelitian. Sehingga diharapkan proses ini dapat menjadi acuan terhadap proses-proses selanjutnya.

c. Design (Desain)

Pada tahap design, penulis merancang perangkat lunak berupa aplikasi yang menjadi hasil penelitian ini. Diharapkan dengan adanya tahapan design ini, permasalahan akan menjadi prosedur dari proses analisis.

d. Implementation (Pemakaian)

Pada tahap implementasi, penulis menerapkan penelitian ini pada sebuah aplikasi yang dirancang untuk memecahkan permasalahan. Diharapkan aplikasi yang dihasilkan nantinya dapat menjadi media share penyebaran informasi lalu lintas yang bermanfaat bagi para pengemudi.

e. Testing (Pengujian)

Pada tahap testing, hasil penelitian ini akan diujicobakan sehingga hasilnya akan terlihat apakah aplikasi ini dapat berjalan dengan baik atau tidak. Tahapan testing ini dilakukan berulang-ulang untuk mengetahui apakah aplikasi ini memiliki tingkat kesalahan kecil atau besar.

\section{b. Interaksi PHP dengan database MySQL}

Untuk dapat menghubungkan database dengan program aplikasi PHP, kita memerlukan fungsi API yang dimiliki oleh database itu sendiri. MySQL adalah sebuah database yang mampu berinteraksi dengan aplikasi apa saja. Umumnya semua database menggunakan ODBC sebagai komponen penghubung database dengan aplikasi program akan tetapi, MySQL telah menyiapkan beberapa API selain ODBC untuk dapat berinteraksi dengan PHP. Fungsi-fungsi itu diantaranya adalah mysql_connect(), mysql_select_db(), dan sebagainya (Bunafit Nugroho, 2004).

Salah satu script menampilkan daftar semua produk menggunakan perintah SQL

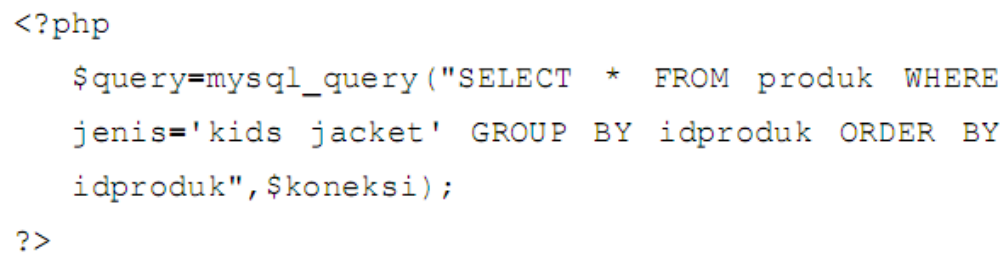




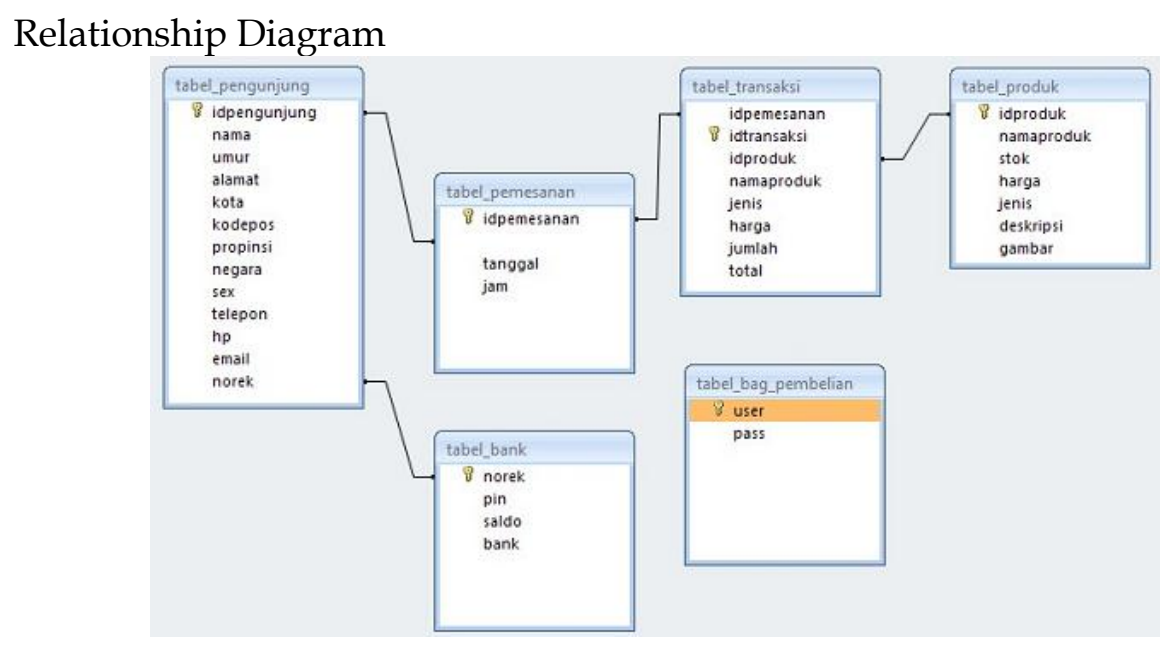

\section{PENUTUP}

Analisis dan perancangan sistem penjualan produk garment pada Perusahaan garment, maka dapat ditarik kesimpulan :

1. Sistem Penjualan produk garment ini merupakan media transaksi secara online yang dapat dijadikan sebagai sarana transaksi alternatif selain proses pejualan yang sebelumnya dilakukan dengan tatap muka antara pembeli dengan pihak perusahaan atau transaksi yang terjadi melalui telepon, pos atau fax, tanpa melihat produk yang ditawarkan lewat katalog oleh perusahaan.

2. Sistem Penjualan produk garment ini dapat juga digunakan sebagai media promosi, sehingga seluruh pelanggan dan masyarakat umum di berbagai daerah dapat memperoleh informasi tentang Perusahaan garment dengan mudah, cepat dan murah tanpa mengenal batas jarak dan waktu.

3. Melalui database yang ada, file-file yang berhubungan dengan seluruh transaksi dapat disimpan sehingga data yang dihasilkan selalu terjamin dan up to date sesuai dengan data yang sebenarnya.

\section{DAFTAR PUSTAKA}

Assauri, Sofyan, SE, MBA. 1992. Manajemen Pemasaran Dasar, Konsep dan Strategi. Edisi Pertama, Cetakan Ke empat. Penerbit Rajawali, Jakarta.

Andriana, Dian. 2003. Pengenalan Pemrograman Sistem Penjualan dengan PHP dan MySQL. Ilmukomputer.com.

Fathansyah, Ir. 1995. Basis Data. Penerbitan Informatika. Bandung.

Henry C, Lucas. 1976. The Analysis Design and Implementation of information Systems. Mc. Graw Hill, Network.

Jogiyanto, HM. 1999. Analisis dan Desain Sistem Informasi : Pendekatan Terstruktur Teori dan Paktek Aplikasi Bisnis, Edisi kedua, cetakan pertama, Andi Offset. Yogyakarta. 


\section{BIODATA DIRI}

$\begin{array}{ll}\text { Nama } & \text { : Tri Listyorini } \\ \text { NIDN } & : \text { O616088502 } \\ \text { Riwayat Pendidikan } & \\ \quad \text { S1 } & \text { : TI - Universitas Dian Nuswantoro Semarang (2007) } \\ \text { S2 } & \text { : TI - Universitas Dian Nuswantoro Semarang (2010) } \\ \text { Jurusan } & \text { : Teknik Informatika } \\ \text { Fakultas } & \text { : Teknik } \\ \text { Universitas } & \text { : Universitas Muria Kudus (UMK) } \\ \text { Email } & \text { : trilistyorini.ti.umk@gmail.com } \\ \text { Publikasi Sebelumnya } & :-\end{array}$

